Brief Report

\title{
Design for Circularity Guidelines for the EEE Sector
}

\author{
Anton Berwald ${ }^{1, *} \mathbb{C}$, Gergana Dimitrova ${ }^{1}$, Thijs Feenstra ${ }^{2}$, Joop Onnekink ${ }^{2}$, Harm Peters ${ }^{2}$, Gianni Vyncke ${ }^{3}$ \\ and Kim Ragaert ${ }^{3}$ (D) \\ 1 Environmental \& Reliability Engineering, Fraunhofer Institute for Reliability and Microintegration IZM, \\ 13355 Berlin, Germany; gergana.dimitrova@izm.fraunhofer.de \\ 2 Pezy Group Groningen, 9723 TV Groningen, The Netherlands; t.feenstra@pezygroup.com (T.F.); \\ j.onnekink@pezygroup.com (J.O.); p_harm@hotmail.com (H.P.) \\ 3 Center for Polymer \& Material Technologies, Department of Materials, Textiles and Chemical Engineering, \\ Faculty of Engineering \& Architecture, Ghent University, B-9052 Zwijnaarde, Belgium; \\ Gianni.Vyncke@UGent.be (G.V.); Kim.Ragaert@UGent.be (K.R.) \\ * Correspondence: anton.berwald@izm.fraunhofer.de
}

Citation: Berwald, A.; Dimitrova, G.; Feenstra, T.; Onnekink, J.; Peters, H.; Vyncke, G.; Ragaert, K. Design for Circularity Guidelines for the EEE Sector. Sustainability 2021, 13, 3923. https://doi.org/10.3390/su13073923

Academic Editor: Vladimir Strezov

Received: 14 March 2021

Accepted: 30 March 2021

Published: 1 April 2021

Publisher's Note: MDPI stays neutral with regard to jurisdictional claims in published maps and institutional affiliations.

Copyright: (C) 2021 by the authors Licensee MDPI, Basel, Switzerland. This article is an open access article distributed under the terms and conditions of the Creative Commons Attribution (CC BY) license (https:// creativecommons.org/licenses/by/ $4.0 /)$.

\begin{abstract}
The increased diversity and complexity of plastics used in modern devices, such as electrical and electronic equipment (EEE), can have negative impacts on their recyclability. Today, the main economic driver for waste electrical and electronic equipment (WEEE) recycling stems from metal recovery. WEEE plastics recycling, on the other hand, still represents a major challenge. Strategies like design 'for', but also the much younger concept of design 'from' recycling play a key role in closing the material loops within a circular economy. While these strategies are usually analysed separately, this brief report harmonises them in comprehensive Design for Circularity guidelines, established in a multi-stakeholder collaboration with industry leaders from the entire WEEE value chain. The guidelines were developed at the product and part levels. They are divided in five categories: (1) avoidance of hazardous substances; (2) enabling easy access and removal of hazardous or polluting parts; (3) use of recyclable materials; (4) use of material combinations and connections allowing easy liberation; (5) use of recycled materials. These guidelines are the first harmonised set to be released for the EEE industry. They can readily serve decision-makers from different levels, including product designers and manufacturers as well as policymakers.
\end{abstract}

Keywords: plastics; recycling; WEEE; design guidelines; design for recycling; design from recycling; circular economy

\section{Introduction}

The annual global plastics production increased from 1.5 million tonnes in 1950 to 368 million tonnes in 2019 [1,2]. Ongoing innovation in the plastics industry has made it possible to use less material to deliver the same or better functionality. However, the increased diversity and complexity of plastics used in modern devices (such as electrical and electronic equipment (EEE)) has negative impacts on the later stages of a product's lifecycle [3,4].

Waste electrical and electronic equipment (WEEE) is considered one of the fastestgrowing waste streams in the EU and at the global level. According to the latest Global E-Waste Monitor, a record 53.6 million metric tonnes (Mt) of electronic waste was generated worldwide in 2019, up 21\% in just five years [5]. Today, the main economic driver for WEEE recycling stems from the recovery of precious metals such as gold, silver, palladium, and copper. WEEE plastics recycling still represents a major challenge, since the plastic fraction is composed of a complex mix of many different polymers and additives. The dominant plastics in WEEE include acrylonitrile butadiene styrene (ABS), high-impact polystyrene (HIPS), polycarbonate (PC), PC/ABS blends, and polypropylene (PP) [3].

While recycling technologies in mechanical and chemical recycling have advanced in the past, the increasing complexity of the WEEE plastics mix makes it more challenging to 
recover all the different polymers, for technical or economic reasons [6]. More than $80 \%$ of the environmental impact of a product is determined at the design stage [7]. Therefore, the initial design of electrical and electronic equipment is key for recycling at their end of life, and design for recycling concepts are needed to meet the recyclers' feedstock requirements. However, not only design 'for' but also design 'from' recycling strategies play a key role in closing the material loop and reaching recycling targets [6].

As one part of the implementation of the first European Circular Economy Action Plan (CEAP) [8], the European Commission (EC) adopted a Europe-wide Strategy for Plastics in the Circular Economy in 2018 [9]. This strategy aims to transform how plastics and plastic products are designed, produced, used, and recycled in the future. Furthermore, the EC set the ambitious goal that 10 million tonnes of recycled plastics should find their way into new products on the EU market by 2025, as compared to the less than four million tons in 2016 [10]. The second CEAP, published in March 2020, reinforces the strategy towards more resource-efficient electronics and better plastics recycling [11].

Since stakeholder engagement will be crucial to reach this ambitious target, the EC launched the Circular Plastics Alliance (CPA) in 2018. The CPA brings together public and private stakeholders in the plastics value chain to promote voluntary actions and commitments for more recycled plastics. The stakeholders pledged to use or produce more recycled plastics, with the overall goal of reaching the 10 million tonne target by 2025 . Furthermore, the CPA made the commitment to "develop, update or revise design for recycling guidelines for all plastic products and ensure they are revised on a regular basis to take into account innovation" [12]. A study conducted for the Joint Research Centre (JRC) of the EC in 2020 to establish a work plan to develop guidelines and standards on design for recycling of plastic products showed that many different guidelines exist for the packaging sector, but that specific readily available guidelines for the EEE sector are barely available [13].

To achieve sustainability-oriented innovation within the plastics industry that allows for increasing the share of recyclates in higher-value applications (such as new EEE), guidelines and standards on responsible design and minimum quality are needed [14]. This brief report aims to contribute towards filling this gap.

\section{Materials and Methods}

The topic of 'design for $X^{\prime}$ (DfX), where ' $X$ ' can represent numerous traits or features of a product or system including reliability, manufacturability, power, variability, cost, yield, environment, etc., has been broadly discussed in the scientific literature in recent decades. In the case of 'design for the environment', further distinctions can be made, e.g., in Design for Multiple Life Cycles [15], Design for Disassembly and Reassembly [16,17], Design for Remanufacturing [18-20], Design for Recycling [21], Design for End-of-Life [22], etc. A

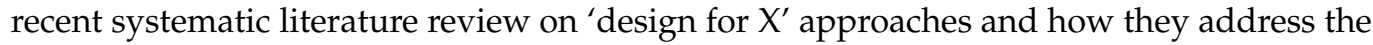
circular economy research context was recently performed by Sassanelli et al. [23] and is not the focus of this brief report, which takes a more practical and industry-based approach.

A variety of practical guidelines to support design for plastics recycling has been published in grey literature in recent years, with an almost exclusive focus on the packaging sector $[13,24-28]$, since packaging represents the highest demand for plastics and also generates most of the plastic waste [1]. Only a few practical and readily applicable guidelines focusing on EEE exist and these do not explicitly take into consideration the product development process on the product and part level and the use of recycled materials [21,29-31].

Design 'from' recycling is a younger concept aiming to incorporate recycled content in new EEE [32-34]. Some guidelines for the EEE sector are available, such as the Designing with Recycled Plastics booklet [35], which provides guidelines on the company level to help manufacturers start using recycled plastics, or the Design from Recycling manual [36]. The latter has the objective of providing companies with the knowledge and support to 
design and produce products from recycled plastics and to estimate the sustainability of these products.

The concept of the Circular Economy is based on the idea of switching from linear thinking to circular thinking throughout the entire value chain. However, despite their inherent complementarity, the concepts of design 'for' and 'from' recycling are often treated separately. This is mainly related to the fact that two different 'worlds' operate almost independently of each other in practice: the world of product development (product designers and manufacturers) and the world of material recovery, which starts at a product's end of life and involves waste collectors, sorters, and recyclers. Figure 1 illustrates the division between the two worlds, which can be bridged by design 'for' recycling at Gate A and design 'from' recycling at Gate B.

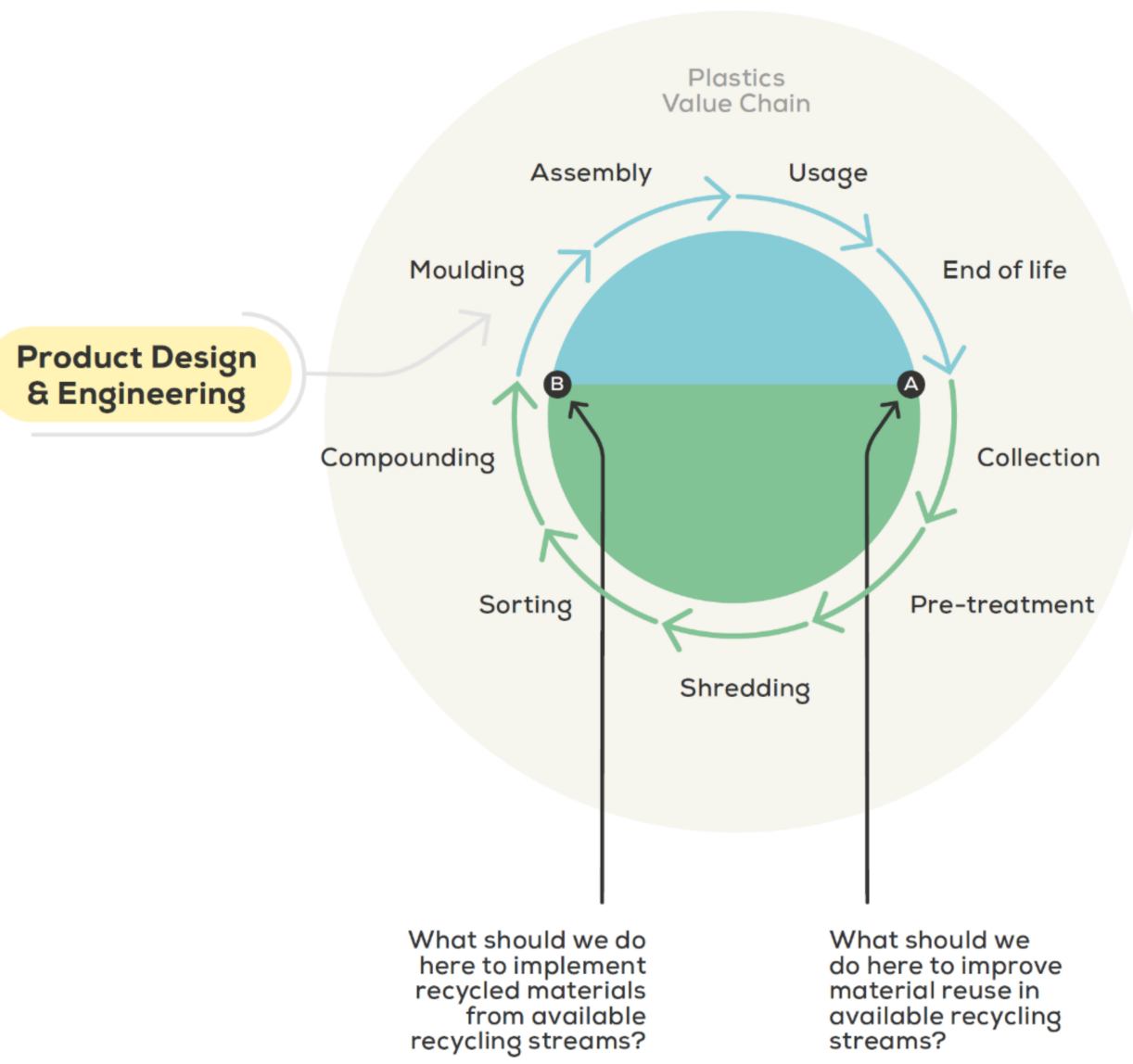

Figure 1. Bringing together the world of product development and the world of material recovery, according to the Pezy Group.

However, only by keeping in mind the connection of both 'gates' will it become possible to develop comprehensive Design for Circularity guidelines. For this purpose, a multi-stakeholder collaboration was established across the entire WEEE value chain within the H2020 project PolyCE, including - in addition to the authors' organisations- the companies Philips (Original Equipment Manufacturer), Imagination Factory (product designers), Erion (Extended Producer Responsibility System), ecosystem (Extended Producer Responsibility System), MGG Polymers (WEEE recycler), SWEEEP Kuusakoski (WEEE recycler), Enva (recycler), and Sun recycling (recycler).

The first set of draft guidelines was established in close collaboration between Fraunhofer IZM and MGG Polymers and was presented at the Going Green CARE Innovation 2018 conference [37], where it was taken up by industry, in particular through the European Electronics Recyclers Association (EERA) [38]. In a second step, the guidelines were refined through an iterative improvement process with the manufacturer Philips. Philips had 
developed its own guidelines based on internal company research as well as years of experience working with numerous recyclers in different countries [21]. In a third step, the results were further improved through investigations including site visits at recyclers facilities and multiple expert interviews from the above-mentioned organisations. The guidelines are intended to reflect the latest status of WEEE collection and recycling in the EU but are written in a practical way to be applied by product designers who usually work on different levels. For this purpose, the guidelines are divided into a product level and a part level. The overall concept is shown in Figure 2.

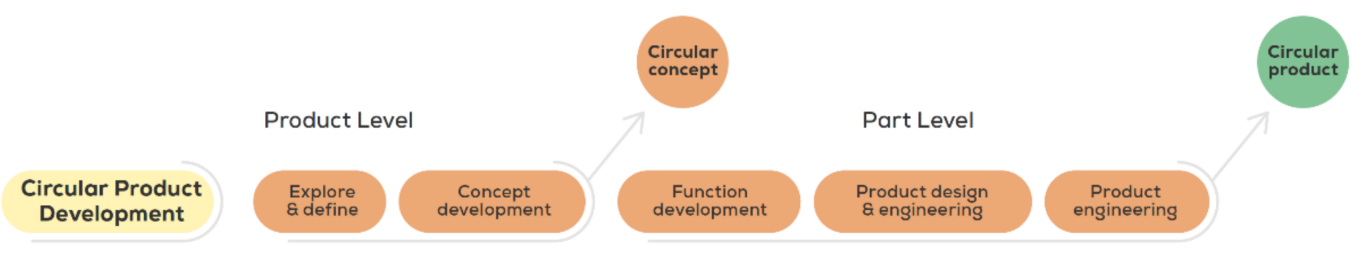

Figure 2. Concept of the design for and design from recycling guidelines, according to the Pezy Group.

On both levels, the guidelines are subdivided into:

1. Avoidance of hazardous substances

2. Enabling easy access and removal of hazardous or polluting parts

3. Use of recyclable materials that will be recycled by WEEE recyclers

4. Use of material combinations and connections that allow easy liberation

5. Use of recycled materials.

\section{Results}

\subsection{Product Level-From Start to Concept}

This sub-chapter provides guidelines on the product level, which typically covers the stages from the start of a project until the validation of the concept. The guidelines and the underlying rationale are summarised in Table 1.

\subsection{Part Level-From Concept to Production}

This sub-chapter provides guidelines at the part level where the concept is brought to the concrete production of the product. This stage includes the function development, design, and engineering of the specific parts of the product and the production. The guidelines and their rationale are summarised in Table 2. 
Table 1. Design guidelines on the product level. WEEE: waste electrical and electronic equipment.

\begin{tabular}{ll}
\hline \multicolumn{1}{c}{ Guidelines and Design Strategies } & \multicolumn{1}{c}{ Rationale } \\
\hline \multicolumn{1}{c}{ Enabling easy access and removal of hazardous or polluting parts } \\
\hline & $\begin{array}{l}\text { Annex VII of the WEEE Directive requires selective treatment for several } \\
\text { materials and components, such as batteries, which should be removed } \\
\text { from any separately collected WEEE stream [39]. If not detected and }\end{array}$ \\
$\begin{array}{l}\text { Use click/snap solutions to fix batteries in a product. } \\
\text { Avoid permanent fixing such as glued, welded, and } \\
\text { enclosed solutions. }\end{array}$ & $\begin{array}{l}\text { during the recycling process. } \\
\text { When using Li-ion batteries, hard cells should be preferred. Soft Li-ion } \\
\text { batteries can be more easily damaged, which constitutes a safety and fire } \\
\text { risk. }\end{array}$ \\
\hline
\end{tabular}

Fix valuable parts (e.g., printed circuit boards (PCBs), cables, wires, and motors) in a product with metal screws, click fingers, press-fit, shrink foil, self-screwed/tapering, or connectors. Avoid permanent fixings such as pressure sensitive adhesive (PSA) tapes, glue, and welded solutions.

Recycling is mainly driven by economic considerations. Facilitating the separation of valuable parts will lead to a higher yield and less loss in other material streams. Furthermore, Annex VII of the WEEE Directive requires selective treatment of $\mathrm{PCBs}$ with a surface greater than 10 square centimetres [39].

Some products contain operating liquids and gases that can be hazardous for humans and the environment (e.g., ozone-depleting substances). Annex VII of the WEEE Directive requires selective treatment of chlorofluorocarbons (CFCs), hydrochlorofluorocarbons (HCFCs) or hydrofluorocarbons (HFCs), and hydrocarbons (HCs) as well as gas discharge lamps [39].

Use drains for operating liquids and gasses and enable easy removal of parts such as oil tanks, compressors, and hoses.

Ensuring safe but also easy to find drains or alternative solutions that enable the removal of such liquids and gasses should be considered the design stage.

In the case that drains cannot be implemented, specific markings indicating where the product can be opened can help recyclers during dismantling and depollution.

It is important to provide detachment possibilities for hazardous and polluting parts since they could otherwise pollute the material streams. Annex VII of the WEEE Directive requires selective treatment of hazardous components such as polychlorinated biphenyls containing capacitors, electrolyte capacitors containing substances of concern, mercury containing

Use detachment possibilities for hazardous and polluting parts/materials (e.g., dust bags, lamps, cord sets, cord winders, paper, cardboard, textiles, wood, foams, glass, and ceramics). components or components containing refractory ceramic fibres [39]. Providing detachment possibilities will facilitate compliance and can reduce recyclers' operating costs.

In the case that this is not possible (e.g., for functional reasons), markings can help at the first stage of the dismantling/recycling process where the product breaks open.

Use one module for hazardous parts in the product structure to enable taking out one non-recyclable module instead of searching for several different hazardous parts.

Concentrating hazardous parts on one or very few modules facilitates the recycling process since it is easier for the recycler to detect them during the manual dismantling step instead of searching for multiple parts. This feature saves time and effort in the process, which can help reduce operating costs.

\section{Use of recyclable materials that will be recycled by WEEE recyclers}

Thermosets and composites cannot currently be recycled with existing

Avoid thermosets and composites. technologies. When they are necessary (e.g., for functional reasons), materials outside the density range of commonly recycled plastics $\left(0.85-1.25 \mathrm{~g} / \mathrm{cm}^{3}\right)$ should be preferred.

Do not use plating, galvanizing, and vacuum-metallization as a coating on plastics. The mentioned techniques connect plastics with metals, a combination that cannot be separated in the recycling process. 
Table 1. Cont.

\section{Guidelines and Design Strategies}

Avoid the use of coatings on plastics.

Minimise the use of thermoplastic elastomers.

Avoid the use of foam.

Minimise the use of magnets.

\section{Use of material combinations and connections that allow easy liberation}

All forms of coatings pollute the material stream or make the recycling process more challenging. Coatings change the density of the plastic, which can cause the plastic to end up in the wrong material stream. Printing numbers or lines for level-indication are not considered problematic and are usually better than using a sticker for the same purpose. Other options are screen-printing, in mould texturing or laser engraving.

When a coating is still needed, a density difference $<1 \%$ of the material's weight is acceptable. Multilayer lacquering should always be avoided.

Thermoplastic elastomers are currently not recycled and have to be separated. Particles that are not separated pollute the waste stream.

Foam can lead to issues during the recycling process. When foam is necessary (e.g., for functionality), thermoplastic foam should be preferred to foam from elastomers or thermosets.

Magnets end up in the ferrous material stream, leading to a pollution of the stream. For this purpose, the use of magnets should be reduced to a minimum when the functionality is required and no alternatives are currently available (e.g., neodymium magnets in mobile phones).

$\begin{array}{ll} & \begin{array}{l}\text { It is very challenging to separate different materials that have been joined } \\ \text { by multiple-K processes. They will usually end up as residue or } \\ \text { (depending on the density) pollute other plastic streams. }\end{array} \\ \begin{array}{ll}\text { Avoid moulding different material types together by } \\ \text { multiple-K processes (different plastic materials }\end{array} \\ \begin{array}{ll}\text { Injected into the same mould, over-moulding, or } \\ \text { in-mould decoration). }\end{array} & \begin{array}{l}\text { (e.g., moulding red PP containing antioxidants on black PP containing talc) } \\ \text { multiple-K processes are not an issue. }\end{array} \\ & \begin{array}{l}\text { An in-mould assembly by multiple-K processes that does not result in a } \\ \text { chemical bonding of the materials is acceptable since the materials will be } \\ \text { separated during shredding. }\end{array}\end{array}$

Avoid connections that enclose a material permanently. Avoid methods such as moulding-in inserts into plastics, rivets, staples, press-fits, bolts, bolt and nuts, brazing, welding, and clinching.
The mentioned processes are typical for tightly enclosing materials and should be avoided, if possible. Enclosing a material permanently makes separation more challenging and can pollute the recyclers' waste stream.

\section{Use of recycled materials}

Consider more textured surfaces for injection moulding plastic parts. Avoid uniform high-gloss surfaces.
Traces of elastomers and glass reduce the quality of large high-gloss surfaces. 
Table 2. Design guidelines at the part level. ABS: acrylonitrile butadiene styrene; PP: polypropylene; PC: polycarbonate; HIPS: high-impact polystyrene.

\begin{tabular}{l} 
Guidelines and Design Strategies \\
\hline Avoida \\
Avoid the use of brominated flame retardants (BFRs) \\
such as polybrominated diphenyl ethers (PBDEs), \\
tetrabromobisphenol A (TBBPA), polybrominated \\
biphenyls (PBBs), Hexabromocyclododecane \\
(HBCD), etc., in the product.
\end{tabular}

Avoid the use of substances of very high concern (SVHC) according to the Registration, Evaluation, Authorisation and Restriction of Chemicals (REACH) Regulation [40] and substances classified as carcinogenic (Carc. 1A or 1B), mutagenic (Muta 1A or 1 ), or reprotoxic (Repr. 1A or 1B) by the Classification, Labelling and Packaging (CLP) Regulation in housing/housing parts [41].

\section{Rationale}

\section{voidance of hazardous substances}

According to Annex VII of the WEEE Directive, plastics containing BFRs have to be removed from any separately collected WEEE [39]. Usually, they can be separated by recyclers and end up in incineration. Several BFRs are already restricted, and it is possible that more will be banned in the future. If these substances are used in materials today, it is likely that they will not meet the requirements to be recycled and reused in new products in the future (legacy substances).

If a substance is identified as a SVHC, it is included in the REACH Candidate List. The European Chemicals Agency (ECHA) regularly assesses the substances on the Candidate List to determine if they should be moved to the Authorisation List (Annex XIV). Once a substance is on an Authorisation List, it can only be used or produced with a specific authorisation and under specified circumstances for defined applications. If these substances can be avoided at the design stage today, they will not cause problems in future recyclates.

These substances are mainly used in plastics as surfactants, solvents, stabilizers, plasticizers, anti-corrosions, pigments, and coatings. They should not be used in concentrations above $1000 \mathrm{ppm},(0.1 \%$ per article) per substance.

Avoid the use of substances that are listed on the 'SIN list' [42]. Background: The 'SIN' (substitute it now) list is a list of substances that are not yet restricted but are candidates for the SVHC list in the future (see above). SIN list substances represent an indication of substances to be restricted/banned in the future. If these substances are used in materials today, future waste stream might not meet the requirements to be recycled and reused in new products.

PVC degrades at the typical processing temperatures of other polymers such as ABS, PC, PC/ABS, PP, PA (polyamide), and HIPS. The generated hydrochloride acid corrodes normal extruders and moulds.

Do not use halogenated polymers (e.g., Polyvinyl chloride (PVC), Polytetrafluoroethylene (PTFE)).

\section{Enable easy access and removal of hazardous or polluting parts}

Avoid magnetic parts on printed circuit boards (PCBs).
PCBs contain many valuable non-ferrous metals. If magnets are placed on the PCB, the entire board might end up in the ferrous stream. In this case, the valuable non-ferrous metals are lost and pollute the ferrous stream.

\section{Use of recyclable materials that will be recycled by WEEE recyclers}

Use common plastics in the product such as ABS, PP, PA, PC, PC/ABS, HIPS, PE (polyethylene), where possible.

Avoid polymer blends.
Common plastics can be easily recycled with existing technologies and processes and should be considered as a first choice. If other materials are required, the reasons should be motivated and supported. Other plastics currently occur in too small volumes for economically viable recycling [43]. If other than the common plastics are used, alternatives outside the density range of $0.85-1.25 \mathrm{~g} / \mathrm{cm}^{3}$ should be considered to facilitate separation.

Mono-material streams should be favoured. Blends like

- $\quad \mathrm{POM} / \mathrm{ABS}$ (polyoxymethylene/acrylonitrile butadiene styrene)

- $\quad$ PA/ABS (polyamide/acrylonitrile butadiene styrene)

- $\quad$ PC/PBT (polycarbonate/polybutylene terephthalate)

- $\quad$ PPE/PS (polyphenyl ether/polystyrene)

- $\quad$ PET/PBT (polyethylene terephthalate/polybutylene terephthalate)

pollute material streams (except for PC/ABS, since it can be properly recycled with existing technologies). 
Table 2. Cont.

\section{Guidelines and Design Strategies}

Avoid glass fibre-filled plastics.

Minimise the use of thermoplastic elastomers.

Avoid the use of thermoset rubbers.

Minimise additives in plastic materials.

\section{Rationale}

Glass fibres pollute material streams, reduce mechanical properties (e.g., impact strength), and cause wear. For a high modulus, mineral filled plastics such as PP-talc should be considered, since they can be recycled. Carbon fibres are also considered a better alternative.

Most of the elastomers can be filtered out during the separation steps. Those elastomers that are not filtered out are likely to end up in the PS stream. When elastomers are necessary (e.g., for functionality), minimise their use and choose, if possible, Styrol-Ethylen-Butylen-Styrol (SEBS) based thermoplastic elastomers (TPE). If a SEBS-based TPE ends up in the PS stream, it may act as an impact modifier, causing the least harm. Thermoset rubbers cannot be recycled and should be reduced, if possible. Additives reduce the purity of the plastic streams. For this reason, the real necessity for additives should be evaluated cautiously.

\section{Use material combinations and connections that allow easy liberation}

Avoid fixing ferrous metals to non-ferrous metals in either parts or fasteners. For example, do not use a screw (ferrous metal) to attach a part to aluminium (non-ferrous).
If a product that contains joined ferrous and non-ferrous materials goes into shredding, it is very likely that either the ferrous or the non-ferrous stream will be polluted. The materials are shredded into small pieces and either the screw will go with the host part to the non-ferrous stream or the non-ferrous part will follow the screw into the ferrous stream.

Do not permanently fix aluminium (Al), copper

(including brass), stainless steel, or steel together in the following combinations:

- If the main material in a part is $\mathrm{Al}$ (cast), do not attach a part of stainless steel, or steel on it.

- If the main material in a part is $\mathrm{Al}$ (wrought), do not attach a part of $\mathrm{Al}$ (cast), copper, stainless steel, or steel on it.

- If the main material in a part is stainless steel, do not attach a part of copper on it.

- If the main material in a part is steel, do not attach a part of copper or stainless steel on it. If the main material is copper, do not permanently fix a part of iron, lead, antimony, or bismuth to it.

The listed combinations are based on the thermodynamic properties of the materials, indicating which materials can be combined and which ones cannot. Depending on the main material in a part, smaller amounts of other materials will end up polluting the stream.

Some materials are easy to separate, while others are rather problematic. A good and easily separable material combination will lead to less polluted material streams. Since polluted streams often end up as a waste fraction, this rule can also lead to waste prevention.

\section{Use of recycled materials}

Choose geometries for injection-moulded parts that allow easy flow paths. Avoid tight and narrow geometries.

For injection mould plastic parts, do not use long injection paths.

For injection mould plastic parts, consider more or wider venting ports.

Use virgin plastics for very demanding parts (e.g., transparent light guides).
High shear rates caused by narrow geometries can stress and degrade polymers.

Recycled polymers are more sensitive to shear and temperature. A possible solution could be the use of multiple injection points. Consider increasing the wall thickness.

Recycled polymers can have higher emissions during production due to pollutants or degrading polymers.

Recycled plastics are different from virgin plastics and cannot as yet meet every demanding requirement.

\section{Discussion and Conclusions}

The main objective of this brief report was to provide Design for Circularity guidelines for the EEE sector that include aspects of design 'from' recycling as well as design 'for' recycling, with a focus on the circularity of plastics. While these approaches handle the start and end of life respectively, they are not just complementary but also synergetic. 
Adherence to design for recycling is expected to reduce challenges faced in design from recycling, as problematic materials and components will have been reduced at least.

The topic of DfX strategies has been discussed in academic literature for many years, but practical and up-to-date guidelines that were co-constructed with and validated by industry leaders are scarce. The results presented in this report are the outcome of a perennial multi-stakeholder collaboration along the entire EEE manufacturing and WEEE plastics recycling value chain, including designers, original equipment manufacturers (OEMs), extended producer responsibility systems, and recyclers. The authors are aware that this is an unconventional approach in scientific literature. However, for any such guidelines to find a broad and willing uptake in the industry, these stakeholders need to feel engaged and to know that their practical day-to-day concerns have been considered and addressed. It is our firm belief that these guidelines, having been co-developed by leaders in EEE manufacturing and the recycling industry, are an important added value to future sector-wide acceptance and integration of the guidelines.

The guidelines provide practical rules and design strategies at the product and part levels and can help designers and manufacturers of EEE to improve the circularity of their products. As an example, they present a highly relevant input for the ongoing sector-specific work of the Circular Plastics Alliance that has the objective of boosting the EU market for recycled plastics to 10 million tonnes by 2025. In its declaration, the CPA made a commitment to "develop, update or revise design for recycling guidelines for all plastic products and ensure they are revised on a regular basis to take into account innovation" [12]. The guidelines developed in this report can readily serve as an input for the CPA for the EEE sector.

Furthermore, they can also be useful for policymakers as a direct technical input for policy instruments and initiatives to take better into account material efficiency aspects for a product category where the ecodesign focus has been mostly on energy efficiency so far [8]. As an example, the guidelines could be used as input for the ongoing revision of the Methodology for Ecodesign of Energy-related Products (MEErP) which is planned to be finalised by the end of 2021. Moreover, the findings could contribute to possible future product-specific standardisation work as a follow-up of the recently published CEN/CLC/JTC 10 horizontal standards on material efficiency aspects for ecodesign of energy-related products and in particular the general methods for assessing the recyclability and recoverability of energy-related products (EN 45555:2019) [44]. In line with the revision of the MEErP and recent standardization work, the present guidelines could also be taken up by the Sustainable Products Initiative that will revise and extend the Ecodesign Directive and propose additional legislative measures to make products placed on the EU market more sustainable [45].

To the best of our knowledge, the guidelines present the current state of the art. However, since materials and processes are constantly evolving, they should be seen as a living document and might need to be updated in the future. Future research could furthermore analyse requirements and opportunities for cluster-specific guidelines, e.g., being based on the categories of electrical and electronic equipment defined in Annex III of the WEEE Directive [39].

Author Contributions: Conceptualization: A.B., G.D., T.F., J.O., G.V. and K.R.; Methodology: A.B., G.D., T.F., J.O., G.V. and K.R.; Validation (of the guidelines): T.F. and J.O.; Investigation: A.B., T.F., H.P. and G.V.; Writing-original draft preparation: A.B., T.F., H.P. and G.V.; Writing-review and editing, A.B., G.D., T.F., J.O., G.V. and K.R.; Visualization: T.F. and J.O.; Supervision: A.B. and K.R.; Project administration: A.B.; Funding acquisition: G.D. All authors have read and agreed to the published version of the manuscript.

Funding: This research was funded by the EU Horizon 2020 Research and Innovation Program under the Grant Agreement number 730308.

Institutional Review Board Statement: Not applicable.

Informed Consent Statement: Not applicable. 


\section{Data Availability Statement: Not applicable.}

Acknowledgments: This document is the outcome of research performed within the PolyCE project. It is based on Deliverable 8.1.: "Guidelines on life cycle thinking integration and use of PCR plastics in new electronic products", which is the outcome of almost four years of close collaboration between the project partners and several external experts. The authors would like to thank all involved parties and in particular Philips, MGG Polymers, Erion, Imagination Factory, Enva, Sun recycling, SWEEEP, Kuusakoski, and ecosystem.

Conflicts of Interest: The authors declare no conflict of interest. The funders had no role in the design of the study; in the collection, analyses, or interpretation of data; in the writing of the manuscript, or in the decision to publish the results.

\section{References}

1. Plastics Europe. Plastics-The Facts 2020: An Analysis of European Plastics Production, Demand and Waste Data. 2020. Available online: https: / / www.plasticseurope.org/en/resources/publications / 4312-plastics-facts-2020 (accessed on 26 January 2021).

2. Statista. Production of Plastics Worldwide from 1950 to 2018. Available online: https://www.statista.com/statistics/282732 / global-production-of-plastics-since-1950/ (accessed on 26 January 2021).

3. Achilias, D.S.; Antonakou, E.V. Chemical and Thermochemical Recycling of Polymers from Waste Electrical and Electronic Equipment. In Recycling Materials Based on Environmentally Friendly Techniques; Achilias, D.S., Ed.; InTech: London, UK, 2015; ISBN 978-953-51-2142-8.

4. Delva, L.; Hubo, S.; Cardon, L.; Ragaert, K. On the role of flame retardants in mechanical recycling of solid plastic waste. Waste Manag. 2018, 82, 198-206. [CrossRef] [PubMed]

5. Forti, V.; Baldé, C.P.; Kuehr, R.; Bel, G. The Global E-Waste Monitor 2020: Quantities, Flows and the Circular Economy Potential; United Nations University (UNU)/United Nations Institute for Training and Research (UNITAR)—Co-Hosted SCYCLE Programme, International Telecommunication Union (ITU) \& International Solid Waste Association (ISWA): Bonn, Germany; Geneva, Switzerland; Rotterdam, The Netherlands, 2020.

6. Ragaert, K.; Delva, L.; van Geem, K. Mechanical and chemical recycling of solid plastic waste. Waste Manag. 2017, 69, 24-58. [CrossRef] [PubMed]

7. European Commission. Ecodesign Your Future-How Ecodesign Can Help the Environment by Making Products Smarter. 2012. Available online: https:/ / op.europa.eu/de/publication-detail/- / publication/4d42d597-4f92-4498-8e1d-857cc157e6db (accessed on 26 January 2021).

8. European Commission. COM (2015) 614 Final-Closing the Loop—An EU Action Plan for the Circular Economy; European Commission: Brussels, Belgium, 2015.

9. European Commission. A European Strategy for Plastics in a Circular Economy. 2018. Available online: https://ec.europa.eu/ environment/circular-economy/pdf/plastics-strategy-brochure.pdf (accessed on 26 January 2021).

10. European Commission. Assessment Report of the Voluntary Pledges under Annex III of the European Strategy for Plastics in a Circular Economy. 2019. Available online: https://ec.europa.eu/docsroom/documents/34267?locale=de (accessed on 26 January 2021).

11. European Commission. A New Circular Economy Action Plan. For a Cleaner and More Competitive Europe. 2020. Available online: https: / / eur-lex.europa.eu/legal-content/EN/TXT/ ?qid=1583933814386\&uri=COM:2020:98:FIN (accessed on 26 January 2021).

12. Circular Plastics Alliance. Declaration of the Circular Plastics Alliance. 2019. Available online: https:/ / ec.europa.eu/docsroom/ documents/36361 (accessed on 26 January 2021).

13. Watkins, E.; Romagnoli, V.; Kirhensteine, I.; Ruckley, F.; Kreißig, J.; Mitsios, A.; Pantzar, M. Support to the Circular Plastics Alliance in Establishing a Work Plan to Develop Guidelines and Standards on Design-for Recycling of Plastic Products; Publications Office of the European Union: Luxembourg, 2020.

14. CEN/CENELEC. Standardization in a Circular Economy-Closing the Loop. 2020. Available online: https: / / www.cencenelec. eu/news/publications/Publications/CEN-CENELECCircularEconomyAccess_rev2020-05-V1.pdf (accessed on 26 January 2021).

15. Go, T.F.; Wahab, D.A.; Hishamuddin, H. Multiple generation life-cycles for product sustainability: The way forward. J. Clean. Prod. 2015, 95, 16-29. [CrossRef]

16. Kuo, T.C. Waste electronics and electrical equipment disassembly and recycling using Petri net analysis: Considering the economic value and environmental impacts. Comput. Ind. Eng. 2013, 65, 54-64. [CrossRef]

17. Vanegas, P.; Peeters, J.R.; Cattrysse, D.; Tecchio, P.; Ardente, F.; Mathieux, F.; Dewulf, W.; Duflou, J.R. Ease of disassembly of products to support circular economy strategies. Resour. Conserv. Recycl. 2018, 135, 323-334. [CrossRef] [PubMed]

18. Peeters, J.R.; Vanegas, P.; Dewulf, W.; Duflou, J.R. Economic and environmental evaluation of design for active disassembly. J. Clean. Prod. 2017, 140, 1182-1193. [CrossRef] 
19. Sundin, E. Product and Process Design for Successful Remanufacturing; Department of Mechanical Engineering: Linköping, Sweden, 2004; ISBN 9185295736.

20. Wahab, D.A.; Blanco-Davis, E.; Ariffin, A.K.; Wang, J. A review on the applicability of remanufacturing in extending the life cycle of marine or offshore components and structures. Ocean Eng. 2018, 169, 125-133. [CrossRef]

21. Hultgren, N. Guidelines and Design Strategies for Improved Product Recyclability: How to Increase the Recyclability of Consumer Electronics and Domestic Appliances through Product Design. Master's Thesis, Chalmers University of Technology, Gothenburg, Sweden, 2012.

22. Rose, C.M. Design for Environment: A Method for Formulating Product End-of-Life Strategies; Stanford University: Stanford, CA, USA, 2000

23. Sassanelli, C.; Urbinati, A.; Rosa, P.; Chiaroni, D.; Terzi, S. Addressing circular economy through design for X approaches: A systematic literature review. Comput. Ind. 2020, 120, 103245. [CrossRef]

24. EPBP. Design Guidelines (Updated Regularly). Available online: https://www.epbp.org/design-guidelines/products (accessed on 26 January 2021).

25. KIDV. Recycle Check. 2019. Available online: https://kidv.nl/KIDV-Recycle-Check-for-rigid-plastic-packaging (accessed on 26 January 2021).

26. Recoup. Recyclability by Design 2020. 2020. Available online: https://www.recoup.org/p/173/recoup-reports (accessed on 26 January 2021).

27. RecyClass. Design for Recycling Guidelines. 2018. Available online: https://recyclass.eu/recyclass/definition/ (accessed on 26 January 2021).

28. SUEZ.circpack. Design for Recycling Guidelines. 2019. Available online: https://www.suez.com/-/media/suez-global/files/ publication-docs / pdf-english/circpack/circpack-guidelinesd4r-v619-07-2019-eng.pdf (accessed on 26 January 2021).

29. American Plastics Council. A Design Guide for Information and Technology Equipment. 1995. Available online: https: // plastics.americanchemistry.com/Design-Guide-for-Information-and-Technology-Equipment/ (accessed on 26 January 2021).

30. Dimitrova, G.; Schischke, K.; Walther, C.; Deubzer, O.; Rückschloss, J.; Berwald, A. Guidelines for Ecodesign: Close WEEE Deliverable 9.4; Fraunhofer IZM: Berlin, Germany, 2018.

31. Ecosystem. Good Design Practices in Preparation for End-of-Life. Available online: https://www.ecosystem.eco/en/article/ good-design-practices (accessed on 26 January 2021).

32. Ragaert, K.; Huysveld, S.; Vyncke, G.; Hubo, S.; Veelaert, L.; Dewulf, J.; Du Bois, E. Design from recycling: A complex mixed plastic waste case study. Resour. Conserv. Recycl. 2020, 155, 104646. [CrossRef]

33. Ragaert, K.; Hubo, S.; Delva, L.; Veelaert, L.; Du Bois, E. Upcycling of contaminated post-industrial polypropylene waste: A design from recycling case study. Polym. Eng. Sci. 2018, 58, 528-534. [CrossRef]

34. Vyncke, G.; Onnekink, J.; Feenstra, T.; Ragaert, K. Design from recycling for post-consumer WEEE plastics. In Proceedings of the International Conference on Polymers and Moulds Innovations-PMI 2018, Universidade do Minho, Guimaraes, Portugal, 19-21 September 2018.

35. Partners for Innovation. Designing with Recycled Plastics. 2015. Available online: https:/ /www.partnersforinnovation.com/wpcontent/uploads/2020/05/Caseguide-Designing-with-Recycled-Plastics-digitaal-spreads.pdf (accessed on 26 January 2021).

36. Du Bois, E.; Doorsselaer, K.; Veelaert, L.; Ragaert, K.; Hubo, S. Design from Recycling Manual. Available online: https: / /www.researchgate.net/publication/324220953_DESIGN_FROM_RECYCLING_MANUAL (accessed on 26 January 2021).

37. Berwald, A. PolyCE Deliverable 2.2—Requirement-Specific Priority Plastics Guide; Fraunhofer IZM: Berlin, Germany, 2018.

38. Berwald, A.; Dimitrova, G.; Nissen, N.; Lang, K.-D.; Schwesig, A.; Chancerel, P.; Emmerich, J. Design for Recycling: A Priority Plastics Guide for WEEE Recycling. Going Green-CARE INNOVATION 2018, Vienna, Austria. 27 November 2018. Available online: https: / / www.eera-recyclers.com/files / 20181129-berwald-polyce-d4r.pdf (accessed on 26 January 2021).

39. European Commission. Directive 2012/19/EU of the European Parliament and of the Council. 2012. Available online: https: / / eur-lex.europa.eu/legal-content/EN/TXT/PDF/?uri=CELEX:32012L0019\&from=DE (accessed on 26 January 2021).

40. European Commission. Regulation (EC) No 1907/2006 of the European Parliament and of the Council on the Registration, Evaluation, Authorisation and Restriction of Chemicals (REACH). 2006. Available online: https://eur-lex.europa.eu/legalcontent/EN/TXT/PDF/?uri=CELEX:02006R1907-20200824\&from=en (accessed on 26 January 2021).

41. European Commission. Regulation (EC) No 1272/2008 of the European Parliament and of the Council of 16 December 2008 on Classification, Labelling and Packaging of Substances and Mixtures, Amending and Repealing Directives 67/548/EEC and 1999/45/EC, and Amending Regulation (EC) No 1907/2006. 2008. Available online: https:/ / eur-lex.europa.eu/legal-content/ EN/TXT/?uri=CELEX\%3A02008R1272-20201114 (accessed on 26 January 2021).

42. chemsec. SIN LIST. Available online: https:/ / sinlist.chemsec.org/ (accessed on 26 January 2021).

43. Slijkhuis, C. Verfügbarkeit von Kunststoffrezyklaten und -qualitäten für Elektro- und Elektronikgeräte: Fachdialog Rezyklateinsatzquote für energieverbrauchsrelevante Produkte unter der Ökodesign-Richtlinie? In Proceedings of the Conference Organised By the German Environment Agency (Umweltbundesamt), online, 20 October 2020; German Environmental Agency: Dessau-Roßlau, Germany, 2020. 
44. CEN/CENELEC. General Methods for Assessing the Recyclability and Recoverability of Energy-Related Products; EN 45555:2019; CEN/CENELEC: Brussels, Belgium, 2019.

45. European Commission. Directive 2009/125/EC of the European Parliament and of the Council of 21 October 2009 Establishing a Framework for the Setting of Ecodesign Requirements for Energy-Related Products (Text with EEA Relevance). 2009. Available online: https:/ / eur-lex.europa.eu/legal-content/EN/ALL/?uri=CELEX\%3A32009L0125 (accessed on 26 January 2021). 